\title{
MAINTAINING EMPLOYEES' MORALITY TO IMPROVE INTERNAL CONTROL IN THE SHARIA MICROFINANCE INSTITUTION
}

\author{
HASAN MUKHIBAD ${ }^{1}$ \\ Universitas Negeri Semarang
}

\begin{abstract}
Problems of fraud committed by a company's internal party are hitherto still problematic to figure out, including in sharia microfinance institutions. This research examines the benefit of maintaining employees' morality for the improvement of internal control in sharia microfinance institution. The object of this research is Anda BMT (sharia microfinance institution in Indonesia). The research uses a qualitative method. The data were obtained by interviewing the managers and twenty employees, and also through field observations for four months. The result of this research shows that the management needs to improve the employees' morality as it is the key element to prevent fraud act. The efforts made to improve the employees' morality are like praying together, joining a program of Islamic study once a week, and targeting all employees to read the Quran at least One Day One Juz (ODOJ). Islamic religious activities should be applied to sharia financial institutions in order to improve the employees' morality and to diminish the act of fraud. It is because the employees who properly carry out Islamic religious activities may reduce the potency of fraud.

Masalah kecurangan (fraud) yang dilakukan oleh pihak internal perusahaan masib menjadi masalah yang sulit dipecabkan sampai saat, termasuk di dalamnya adalab lembaga keuangan syariah. Penelitian ini bertujuan untuk mengeksplorasi model mengembang-
\end{abstract}

Corresponding author; email: 'hasanunnes@gmail.com

ISSN 0852-7172 (p) 2461-064X (e)

(C) 2017 Walisongo: Jurnal Penelitian Sosial Keagamaan

http://journal.walisongo.ac.id/index.php/walisongo 
kan lingkungan pengendali yang digunakan untuk meningkatkan efektifitas sistem pengendalian internal. Obyek penelitian ini adalah BMT Anda. Metode penelitian menggunakan metode kualitatif. Data dikumpulkan dengan metode wawancara dan pengamatan di lapangan selama 4 bulan. Narasumber penelitian adalah manajer, dan 20 karyawan. Hasil penelitian menunjukkan bahwa manajemen memiliki komitmen bahwa etika karyawan merupakan elemen kunci untuk menghindari kecurangan. Upaya untuk menjaga etika karyawan, manajemen mewajibkan karyawan untuk melaksanakan salat berjamaah (Dhubur dan Asar), mengikuti kegiatan pengajian seminggu sekali, dan menargetkan semua karyawan untuk membaca Alquran setidaknya satu hari satu juz (One Day One Juz - ODOJ). Pelaksanaan kegiatan keagamaan Islam harus diterapkan pada lembaga keuangan syariah dalam upaya meningkatkan etika karyawan, selanjutnya akan mengurangi potensi kecurangan. Hal ini dikarenakan karyawan yang melaksanakan kegiatan keagamaan secara benar bisa mengurangi potensi kecurangan.

Keywords: employees' morality; internal control; Islamic religious activities; sharia microfinance institution.

\section{Introduction}

Fraud in banks is still problematic to solve and becomes the most serious problem in business (Hall 2004). Some time ago, several media highlight banking scandals committed by bank employees, leaders, or customers. Even, banking scandals are also committed through cooperation between bank employees and customers. Some banking scandals in Indonesia are such as burglary cases of Citibank costumers, Indonesian State Bank (BNI), Indonesian International Bank (BII), and Victoria Bank (Suprapto 2011).

Some parties consider that banking criminal cases could be minimized by changing the banking operations based on Islamic 
principles. The President Director of Sharia BRI, Ventje Raharjo states that Islamic banking is safer from fraud as it is able to maintain sharia principles (Viva 2011). This is because Islamic financial institutions applies sharia values which is based on Islamic law as their operational foundations, including in corporate cultural development which emphasizes on the attitudes of trust (amānah), excellence (ihsānn) and dignity (faläh) (Saiful et al. 2011; Triyuwono 2004; Nasution 2009).

However, previous studies discovered that fraud cases still occurred in Islamic financial institutions such as burglary case through fictitious loans in Sharia Mandiri Bank and Sharia Central Java Bank (Merdeka 2011). In addition, the case was also found in another type of sharia microfinance institution called Baitul Māl wa Tamwīl (BMT) such as in An Najah BMT and PSU BMT. The fund of An Najah BMT has been corrupted by its employees (Sindo Newspaper, June 26, 2016). Also, misused loans granted by the management and supervisor of BMT have caused to the bankruptcy of BMT (Bisnis.com, July 27, 2015).

Basically, the internal control system developed in sharia banking and BMT is a human-based control system. It means that there is no God's intervention in such system. So, the paradigm used to establish internal control system still applies conventional concept. Such paradigm is ordinarily used by the Muslims in their economic activity (Hashim 2012).

Meanwhile, the basic paradigm used to develop Islamic-based control system is a control system which involves God in any aspect of life. It is because the universe created by God is a mandate from Him and as a means of happiness for the life of human being to gain prosperity both materially and spiritually. It means that according to Islamic view, the whole universe (including job, title, position, and others) is a trustworthiness given by God and must be counted for by all mankind before God. 
Every Muslim must believe on the accountability in the hereafter that everything is accountable before God. In other words, the mankind should accomplish their missions well in this world (al-Quran, al-Nisa; al-Anfal). The result of every human's responsibility then determines whether human will live happily in the hereafter or not.

The aforementioned explanation shows that fraud, in fact, still occurs in Islamic financial institutions. Yet, the research on fraud in Islamic financial institutions is still rarely conducted. Some studies carried out by Nor, Wan, Fathi, \& Puspitasari (2017) found that the case of fraud can be influenced by some factors like gender, age, position and religiosity. A solution to prevent the potency of fraud in Islamic banking is by doing review and improving internal control (Rahman and Anwar 2014). An indicator for internal control is corporate culture. More specifically, the shape of corporate culture can decrease the potency of fraud (Biggerstaff, Cicero, and Puckett 2015). In addition, (Salin, Ahmad Saiful Azlin Puteh; Ab Manan, Siti Khadijah; Nawawi 2017) stated that Islamic ethics can be a solution to reduce the fraud in Islamic banking.

This research was conducted to develop a model for the improvement of employees' morality which is base on the Islamic law and could be properly used in the Islamic financial institutions. This research is necessarily conducted as the previous researches have not developed such model. And, good morality is necessary to reduce fraud that still happens in Islamic financial institutions. It is because the good morality will improve the internal control system and will further decrease the fraud.

This research was conducted with a preliminary study on the implementation of Islamic ethics and the potency of fraud in 10 BMTs. Subsequently, the author determined which BMT that has good ethical implementation and that has lowest fraud 
potency. Finally, the selected BMT becomes the object of this research.

The object of this research is Anda BMT in Salatiga, Central Java, Indonesia. Anda BMT is considered as the object of study as it has good religious development, financial performance, and high-level internal control system based on the previous research.

To achieve the objectives of this research, the author uses qualitative method by applying case study methodology. The case study-based research uses empirical evidences of one organization or more while the author tries to solve the problems and contexts. An interpretative approach is used as this research focuses on stories and arguments related to a phenomenon ( $\mathrm{Sa}$ rosa 2012). Person to person interview was conducted to gain information from the informant (Merriam 2009).

The method of interview by using semi-structured technique is applied to obtain the research data. The research informants are general manager and financial manager and employees. Two informants are determined by management since this research is related to management policy. The other informants are the employee to validate the data obtained from the management party. The interview is not conducted at the same time to ensure the validity of the collected data. In addition, to validate the data, the author uses triangulation method that the data is considered valid if supported by other data, such as observation and statements from other informants (Creswell 2009). Valid data will be interpreted, reconstituted, and concluded (Yin 2011).

\section{Baitul Māl wa Tamwīl}

Baitul Māl wa Tamwīl (BMT) is a sharia microfinance institution. It consists of two phrases baitul māl means house of wealth and bait al-tamwill means house of finance (Kustin 2015). BMT is sharia microfinance institution which applies Islamic 
law (sharia) as the general principles (Daniel and Saeed 2013). The core value of Islamic law is the prohibition of giving interest (riba). According to Kustin (2015), BMT has two functions. The main function is to have a good financial and social performance. Therefore, many studies show that BMT has a positive effect on society, especially in economic empowerment of small communities (Sakti 2013).

BMT business actors have many problems. The main problem faced by BMT is poor business sustainability (Abdul Rahman \& Dean, 2013; Alaeddin \& Anwar, 2012 this evokes anxiety that microfinance institutions will not be able to stay true to their social objectives if they are to access commercial capital. A breakthrough in Islamic micro finance in the form of Islamic cash endowment through cash waqf is aiming to ensure the outreach is still prioritized. This paper analyzes the grass root fact in a case study of an Islamic microfinance institution (MFI; Abdul Rahman \& Dean, 2013). The poor business sustainability is resulted from various problems. Range (2004) reveals that the biggest problem faced by BMT is the weakness in supervision which causes in poor performance and leads to bankruptcy.

Manan \& Shafiai (2015) argue that the poor business sustainability of sharia microfinance institutions is resulted from the poor risk management. In addition, the internal control system of BMT is also weak that results in poor business sustainability (Mukhibad 2014). Thus, good risk management can reduce risks without diminishing its potency to gain profits and BMT's sustainability can also increase.

\section{Islamic Paradigm}

Islam is a perfect religion (al-Quran, al-Maidah). Islam does not only teach how humans worship God, but also manages how they should interact with others. Any kind of relationship 
among men has been set up in Islam, including how the Muslims perform their economic activities. In the Quran, God has said that He has set business rules for human beings (Salin, Ahmad Saiful Azlin Puteh; Ab Manan, Siti Khadijah; Nawawi, 2017; Hashim, 2012)

Some researchers have formulated several Islamic paradigms that should be applied by the Muslims in performing their economic activities. One of them is Islamic work ethics (Syed and Ali 2010; Ali and Al-Owaihan 2008; Khan et al. 2015; Ali and Al-Kazemi 2005; Ali 1992; Beekun 1997). Previous researches frequently use Islamic work ethics as an indicator to measure employees' religiosity (Amaliah, Aspiranti, and Purnamasari 2015; Hejase, Hamdar, and Raslan 2014) which is then connected to the company's performance (Wisker and Rosinaite 2016; Zahrah et al. 2016; Hadisi 2014). Religion can elevate self-control, influence how goals are selected, pursued, and organized and can be self-monitoring tool (Mccullough and Willoughby 2009). However, some previous studies show that a research aiming to develop a model of internal control system based on Islamic paradigm needs to be conducted.

\section{Internal Control System Based on Islamic Paradigm}

Fraud is a crime and an indicator that should be avoided. Tuanakotta (2007) considers that to reduce fraud, a company must implement an effective internal control system. Similar solution is also provided by Committee of Sponsoring Organizations of Tread way Commission (COSO) by issuing 26 fundamental principles for the implementation of internal control system. Those 26 fundamental principles are connected with five key components of internal control system, such as: (1) environment control; (2) risk assessment; (3) control activities; (4) information and communication; and (5) monitoring (Goetsch and Davis 2014). 
Among the five components of internal control, environment control is the most emphasized one by COSO (Doyle, Ge, \& McVay, 2007; Ge \& McVay, 2005; Hanim Fadzil, Haron, \& Jantan, 2005; Hall, 2004). This is because environment control is a major factor used to prevent the risk of misstatement of financial report (Berg and Cassells 1992; Doyle, Ge, and McVay 2007).

The aforesaid hypothesis is in line with the research results conducted by (Puspasari 2012) who finds that there is interaction between individual morality and internal control. The conditions of internal control element do not influence individuals with high morals level who tend not to commit fraud in accountancy. While, individuals with low morals level tend to commit accountancy fraud since the condition is not internal control element. Financial scandals occurring in a company start from ineffective governance issues characterized by the inexistence of ethics within the company (Salin, Ahmad Saiful Azlin Puteh; Ab Manan, Siti Khadijah; Nawawi 2017).

Bologna \& Lindquist (1995) indirectly state that ethics, honesty, is required to reduce fraud. The statement is indirectly expressed in the form of figurative i.e. "some people are honest all the time, some people (fewer than the honest ones) are dishonest all the time, most people are honest all the time, and some people are honest most of the time". This statement indicates that the attitude of someone who is sometimes honest and dishonest has potential to commit fraud. Therefore, re-establishment of an honest culture is very important (Cohn, Fehr, and Maréchal 2014).

In the research aiming to identify the causes of fraud, Albrecht replaces rationalization aspect in fraud triangle theory with personal integrity. Rationalization is a justification of fraudulent behaviour because the employee lacks personal integ- 
rity or moral reasoning (Abdullahi and Mansor 2015). It means that rationalization is more influenced by ethics. Ramamoorti (2008), states that rationalization and pressure are the factors which cause accountancy fraud based on subject's psychological condition. Dorminey, Fleming, Kranacher, \& Riley Jr, (2012) state that rationalization and pressure are the subject's characters to commit accountancy fraud which may not be observed as it is impossible to know what the subject is thinking when committing accountancy fraud. From the statement above, it can be concluded that the accountancy fraud has relationship with ethics (Krummeck, 2000; Liyanarachchi, 2009)

Chapra \& Ahmed (2002) reveals that there are some factors influencing the success of Islamic economic system during the glory of Islam by creating a corporate environment which ensures employees to behave honestly and efficiently. The company success is indication of the company performance as the result of the implementation of Good Corporate Governance (GCG) and shows fraud absence. Thus, we can conclude that upholding trust (amānah) as one of Islamic culture is indispensable for reducing fraud. In more details, Saiful et al. (2011) explain that the company scandals and cases may be avoided through the right approach with religious perspective, particularly Islam.

Ahmad (2004) explains that in Islam God created human being to be a caliph in the world (al-Quran, al-Naml: 62). It means that human beings are not only the caliphs (in this world) but also the agent of God or God's servant and therefore the wealth of human beings must be derived from lawful manner based on Islamic law, not coming from any effort by violating moral values such as stealing, committing fraud and any other injustice acts which break Islamic law (Ahmad, 2004).

Every human being bears responsibility in this world. In Islam, humans have horizontal (hablun min al-nass) and vertical 
(bablun min Allāh) responsibility. The consequence is human morality must conform to God's injunction. Beekun (1997) defines that Islamic ethics as a set of moral principles distinguishes whether something is right or wrong according to Islamic perspective. Therefore, Islamic Work Ethics is defined as a set of moral principles distinguishing right and wrong doing from Islamic perspective (Rokhman 2010).

\section{Results and Discussion}

One of indicators for internal control systems is an environmental control and among the indicators for environment control is cultural control. The culture developed by a company will influence employees' attitude to obey what is legalized and to stay away from all prohibitions. And one of the ways to develop corporate culture is religion. Religion has behaviour control for its adherent. Such control, if it is continually obeyed will later be a religious-based culture.

Based on the observation, it shows that there is one most outstanding BMT in implementing Islamic principles that is Anda BMT in Salatiga, Central Java, Indonesia. The implementation of Islamic ethics which supports the establishment of corporate culture and company internal control system is conducted with the following methods:

First, in the process of recruitment, BMT emphasizes on soft skill values of the applicants. Morals value becomes the main factor for the acceptance of the applicants. BMT concerns more on prospective applicants who bear good manners instead of those who have great competence but low morality. Mr. M, the financial manager said:

"In our recruitment system, we conduct written test and interview. For administration staff, a practical test is also given. For marketing staffs, our marketing division will do an assessment 
on marketing skills. Yet, morality is the most important aspect for us. The applicant with good morality will get more point. So, the primary factor is morality, then followed by other competencies. While, for working performance, we will give them motivations. For the assessment of applicants' religious value, we will concern on their regularity in reading the holy Quran. And, during the interview, we also ask them concerning their activities in mosque, whether they take part actively in religious activities or not. The latter also becomes our main standard."

Similar statement is also given by Mr. S as the general manager.

To obtain prospective employees with good attitude, BMT opens opportunity to its employees to recommend their relatives, friends or other acquaintances to apply. It is because they have been well known through its employees so that it eases BMT to see the background of the applicants, mainly related to their religious background. Mr. S, the general manager, gives statement as follows:

"When we need new employees, we will inform first to our employees. Perhaps, they have relatives, friends or acquaintances who are interested in working at BMT. This is what we believe and we could know them better. We undoubtedly know their background, daily life, and the most important is related to their religious aspect. But, If we make open recruitment, we might not know if the applicant is diligent in doing five-time obligatory prayers, whether they regularly go to the mosque, whether they frequently attend religious teaching, including their competence in reading the holy Quran.”

The statements show that during recruitment process, BMT gives many concerns on the candidate with good religious background. Some indicators used to assess their religious obedience are doing five-time obligatory prayers, actively joining mosque activities, regularly attending religious teaching, as well as regularly reading the holy Quran. 
After the recruitment of new employees, BMT later needs to improve their soft skills by regularly carrying out a program of religious teaching conducted once a week and religious discussions every month. Here are statements given by Mr. M:

"We have routine religious teaching every week and held in all our branches. But, every branch has different schedule like on Friday afternoon or Thursday morning at 8.00 a.m. to 09:00 a.m. The program is for religious teaching only. Any discussion related to working, marketing target, and others are not permitted to discuss. Then, for reading the holy Quran, we have a program called MFA (Major Family Assembly)."

Similar information is also given by Mr. SP. Based on several interviews before, BMT usually maintains the employees' religious awareness by regularly conducting religious teaching weekly. The religious teaching is conducted in every branch with different schedules. The program is necessary and all employees must join. It means that all the employees in one branch are obliged to join the religious teaching held by the related branch office. Once, the religious teaching is held, they are supposed to discuss Islamic teaching and not allowed to discuss anything else related to the job.

Another activity to improve employees' good attitude is by reading the holy Quran. Anda BMT states that in addition to achieving financial target and customer deposits, all employees are also given a daily target to read the Quran. BMT gives a target to finish reading the Quran at least one day one juz (section) for every employee. Once they finish reading the Quran, they have to give report to BMT Management.

Last but not least is the program of conducting daily five prayers together on time. The study found that Anda BMT office has a mosque to perform praying. For the branches which are next to the mosque, the employee must pray in the mosque. When the time for dubur prayer is coming, the muezzin calls 
for prayer in order that all employees and customers go to the mosque and pray together, except those are still giving services to the customers. It is also implemented to Ashar prayer as well.

"If the office is close to the mosque, praying together is our main priority. But, if the office is far away from the mosque, we provide small mosque. So, when duhur and Ashar prayer are coming, the muezzin will be ready to call for prayer. Yet, the services are still given to our customers. They may not join praying together. But, for those who are not giving services to the costumers are obliged to join praying together."

Based on the aforementioned facts, we can see that BMT really emphasizes on the religious aspect of its employees as a major factor to construct institution's internal control system. The management believes that good religious awareness will result in good behaviour of the employees to act in accordance with Islamic teaching. It means that good morality will produce trustworthiness and sincere attitude upon duties, facilities, entrusted position, as well as having falāh-oriented vision. Trustworthiness (amānah), excellence (ihsānn) and dignity (falāh) are the attitudes highly emphasized as a working culture in Islamic financial institutions (Saiful et al., 2011; Triyuwono, 2004)

If associated with COSO model, the establishment of employees' good religious awareness will influence the improvement of internal environment control. Good internal environment control will improve internal control system. Furthermore, a good internal control system will influence to the improvement of BMT performance (Njeri 2014; Muraleetharan 2011; Dineshkumar and Kogulacumar 2011). Concisely, religion can be a proxy to strengthen the ethical norms within the community of the company, and to examine whether such norms could reduce unethical corporate behaviour (Grullon, Kanatas, and Weston 2009). Good morals improvement is the key to prevent the fraud (Salin, Ahmad Saiful Azlin Puteh; Ab Manan, Siti Khad- 
ijah; Nawawi, 2017; Puspasari, 2012). And, religion especially Islam is the important source of ethics (Mukhibad 2014). The obedience of the employee toward Islamic ethics is needed to reduce fraud act (Saiful et al., 2011; Salin, Ahmad Saiful Azlin Puteh; Ab Manan, Siti Khadijah; Nawawi, 2017; Ahmad, 2004; Nasution, 2009).

This is also in accordance with the statement of Saiful et al., (2011) that company scandals and problems can be avoided through the appropriate approach generally by implementing religious teaching, particularly Islamic teaching. In addition, these finding also strengthens the God saying in Surah Al Maidah stating that Islam is the perfect religion. ".... This day I have perfected your religion for you and completed My favour upon you and have chosen Islam as religion for you...." (al-Quran, al-Maidah: 3).

Based on the result, the model for maintaining employees' morality can be seen at figure 1 .

Figure 1.

The model of maintenance of employee ethics

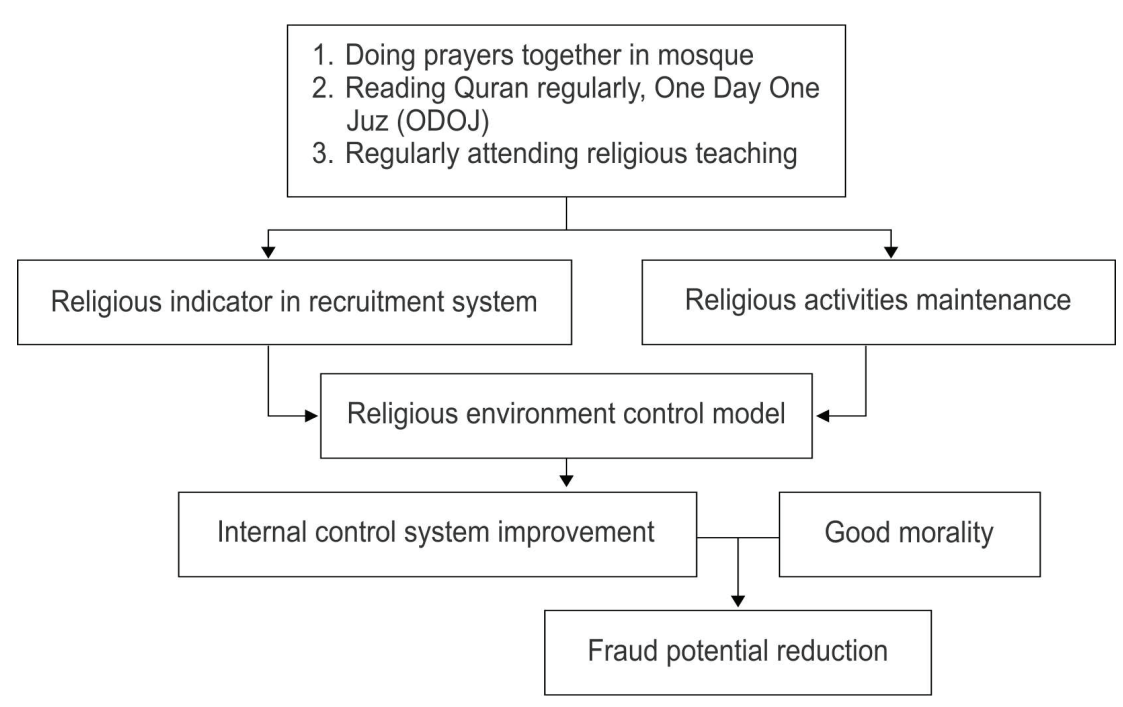




\section{Conclusion}

This research finds that the implementation of internal control system must emphasize on the religious aspect of the employees. The employee with good religious awareness will result in good behaviour which conforms to Islamic law (sharia) and could create the effectiveness for internal control system in BMT. To improve the employees' religious awareness, BMT organizes weekly program such as Islamic Study, praying together, and ODOJ. Besides, BMT also applies certain standard that religious aspect of the applicants or candidates becomes the main factor in the process of recruitment.

Finally, the author suggests that religious aspect of the employee must be the main concern for the establishment of internal environment control in the Islamic financial institutions. The institution should utilize religion especially Islam as the model for effective company management, especially in Islamic-based financial institutions.

\section{Bibliography}

Abdul Rahman, Rashidah, and Faisal Dean. 2013. "Challenges and Solutions in Islamic Microfinance." Humanomics 29 (4): 293-306. doi:10.1108/H-06-2012-0013.

Abdullahi, Rabi 'u, and Noorhayati Mansor. 2015. "Fraud Triangle Theory and Fraud Diamond Theory. Understanding the Convergent and Divergent For Future Research.” International Journal of Academic Research in Accounting Finance and Management Sciences 5 (4): 38-45. doi:10.6007/IJARAFMS/v5-3/1823.

Ahmad, Imad-ad-dean. 2004. "Islam, Commerce, and Business Ethics." In Plenary Address at the Loyola Institute for Ethics and Spirituallity in Business - International Ecumenical Conference, 1-14. 
Alaeddin, Omar, and Nurhayati Anwar. 2012. "Critical Analysis of Diverse Funding of Islamic Microfinance Institution: A Case Study in BMT Amanah Ummah Surabaya Indonesia.” In 2nd ISRA Colloquium 2012 - Islamic Finance in a Challenging Economy: Moving Forward, 2-33.

Ali, Abbas J. 1992. "The Islamic Work Ethic in Arabia." The Journal of Psychology 126 (5). Taylor \& Francis: 507-19.

Ali, Abbas J, and Ali Al-Kazemi. 2005. "The Kuwaiti Manager: Work Values and Orientations." Journal of Business Ethics 60 (1). Springer: 63-73.

Ali, Abbas J, and Abdullah Al-Owaihan. 2008. "Islamic Work Ethic: A Critical Review." Cross Cultural Management: An International Journal 15 (1). Emerald Group Publishing Limited: 5-19.

Amaliah, Ima, Tasya Aspiranti, and Pupung Purnamasari. 2015. "The Impact of the Values of Islamic Religiosity to Islamic Job Satisfaction in Tasikmalaya West Java, Indonesia, Industrial Centre." In 2nd Global Conference on Business and Social Science-2015, 211:984-91. Elsevier B.V. doi:10.1016/j.sbspro.2015.11.131.

Beekun, Rafik Issa. 1997. Islamic Business Ethics. International Institute of Islamic Thought (IIIT).

Berg, Robert L, and Joseph S Cassells. 1992. "Falls in Older Persons: Risk Factors and Prevention.” NCBI. National Academies Press (US).

Biggerstaff, Lee, David C. Cicero, and Andy Puckett. 2015. "Suspect CEOs, Unethical Culture, and Corporate Misbehavior." Journal of Financial Economics 117 (1). Elsevier: 98-121. doi:10.1016/j.jfineco.2014.12.001.

Bologna, Jack, and Robert J Lindquist. 1995. Fraud Auditing and Forensic Accounting: New Tools and Techniques. 2nd ed. John Wiley \& Sons Inc. 
Chapra, Umer, and Habib Ahmed. 2002. Corporate Governance In Islamic Financial Institutions. Islamic Development Bank - Islamic Research and Training Institute. Islamic Development Bank.

Cohn, Alain, Ernst Fehr, and Michel André Maréchal. 2014. "Business Culture and Dishonesty in the Banking Industry.” Nature 516 (7529). Nature Research: 86-89.

Creswell, John. W. 2009. Research Design - Qualitative, Quantitative, and Mixed Methods Approach. London: Sage Publication.

Daniel, C, and Al-Muharrami Saeed. 2013. "Cooperative and Islamic Banks; What Can They Learn from Each Other?" IMF Working Papers 13 (84): 1-31.

Dineshkumar, Sabina, and Priya Kogulacumar. 2011. "Internal Control System and Its Impact on the Performance of the Sri Lanka Telecom Limited in Jaffna District." Faculty of Management Studies \& Commerce, University of Jaffna, Sri Lanka, ISSN, 2319-7900.

Dorminey, Jack, A Scott Fleming, Mary-Jo Kranacher, and Richard A Riley Jr. 2012. "The Evolution of Fraud Theory." Issues in Accounting Education 27 (2). American Accounting Assocation: 555-79.

Doyle, Jeffrey T, Weili Ge, and Sarah McVay. 2007. "Accruals Quality and Internal Control Over Financial Reporting.” The Accounting Review 82 (5): 1141-70.

Ge, Weili, and Sarah McVay. 2005. "The Disclosure of Material Weaknesses in Internal Control after the Sarbanes-Oxley Act." Accounting Horizons 19 (3): 137-58.

Goetsch, David L, and Stanley B Davis. 2014. Quality Management for Organizational Excellence. pearson Upper Saddle River, NJ. 
Grullon, Gustavo, George Kanatas, and James Weston. 2009. "Religion, Ethics, and Corporate Behavior."

Hadisi, Mitra. 2014. "The Effect of Islamic Work Ethics On The Performance Of Muslim Employees Of Marketing Sector In Multinational." International Journal of Organizational Leadership 3: 31-40.

Hall, James A. 2004. "Ethics, Fraud, and Internal Control." In Accounting Information Systems, 4th ed., 1-7. Brisbane: South-Western Publishing Co.

Hanim Fadzil, Faudziah, Hasnah Haron, and Muhamad Jantan. 2005. "Internal Auditing Practices and Internal Control System." Managerial Auditing Journal 20 (8). Emerald Group Publishing Limited: 844-66.

Hashim, Muhammad. 2012. "Islamic Perception of Business Ethics and the Impact of Secular Thoughts on Islamic Business Ethics." International Journal of Academic Research in Business and Social Sciences 2 (3): 98-120.

Hejase, Hussin Jose, Bassam Hamdar, and Mohammad Raslan. 2014. "Business Ethics And Religion In The Financial Business Sector : Case Of Syiria." Journal of Business \& Management 1 (2): 73-113.

Karim, Nimrah, Michael Tarazi, and Xavier Reille. 2008. "Islamic Microfinance : An Emerging Market Niche." Focus Note. doi:10.1355/SJ23-1D.

Khan, Khurram, Muhammad Abbas, Asma Gul, and Usman Raja. 2015. "Organizational Justice and Job Outcomes: Moderating Role of Islamic Work Ethic." Journal of Business Ethics 126 (2). Springer: 235-46.

Krummeck, Steve. 2000. "The Role of Ethics in Fraud Prevention: A Practitioner's Perspective." Business Ethics: A European Review 9 (4). Wiley Online Library: 268-72. 
Kustin, Bridget. 2015. "Islamic (Micro) Finance: Culture, Context, Promise, Challenges." Financial Services for the Poor. Bangladesh: Bill \& Melinda Gates Foundation.

Liyanarachchi, Gregory A. 2009. "Accounting In Ancient Sri Lanka: Some Evidence Of The Accounting And Auditing Practices Of Buddhist Monasteries During 815-1017 AD." Accounting History 14 (1-2). SAGE Publications Sage UK: London, England: 101-20.

Manan, Siti Khadijah Ab, and Muhammad Hakimi Bin Mohd Shafiai. 2015. "Risk Management of Islamic Microfinance (IMF) Product by Financial Institutions in Malaysia." Procedia Economics and Finance 31 (15). Elsevier B.V.: 8390. doi:10.1016/S2212-5671(15)01134-X.

Mccullough, Michael E, and Brian L B Willoughby. 2009. "Religion, Self-Regulation, and Self-Control : Associations, Explanations, and Implications." Psychological Bulletin 135 (1): 69-93. doi:10.1037/a0014213.

Merdeka, Suara. 2011. "Dugaan Pembobolan Dana Nasabah: Giliran Bank Jateng Syariah Diaudit." Suara Merdeka Newspaper, November.

Merriam, Sharan B. 2009. Qualitative Research: A Guide to Design and Implementation. Vol. 53. San Fransisco: The Jossey-Bass. doi:10.1017/CBO9781107415324.004.

Mukhibad, Hasan. 2014. "Dampak Pendidikan Etika Bisnis Dan Pendidikan Ekonomi Syariah Terhadap Etika Bisnis." Jurnal Dinamika Akuntansi 6 (2): 119-32.

Muraleetharan, P. 2011. "Internal Control and Impact of Financial Performance of the Organizations (Special Reference Public and Private Organizations in Jaffna District)." In Intemational Conference on Business \& Information [C/ $\mathrm{OL}]$.

Nasution, Mustafa Edwin. 2009. "Islamic Spirit and Morale in 
Economics." Journal of International Development and Cooperation 15 (1-2): 113-24.

Njeri, C K. 2014. "Effect of Internal Controls on the Financial Performance of Manufacturing Firms in Kenya." Unpublished Thesis.

Nor, Wan, Iffah Wan, Mohd Fathi, and Evita Puspitasari. 2017. "Potential Employee Fraud Scape in Islamic Banks: The Fraud Triangle Perspective." Global Journal Al-Thaqafah 7 (2): 79-94.

Puspasari, Novita. 2012. "Pengaruh Moralitas Individu Dan Pengendalian Internal Terhadap Kecenderungan Kecurangan Akuntansi: Studi Eksperimen Pada Konteks Pemerintahan Daerah.” Universitas Gadjah Mada.

Rahman, Rashidah Abdul, and Irda Syahira Khair Anwar. 2014. "Effectiveness of Fraud Prevention and Detection Techniques in Malaysian Islamic Banks." Procedia - Social and Behavioral Sciences 145. Elsevier B.V.: 97-102. doi:10.1016/j.sbspro.2014.06.015.

Ramamoorti, Sridhar. 2008. "The Psychology and Sociology of Fraud: Integrating the Behavioral Sciences Component into Fraud and Forensic Accounting Curricula." Issues in Accounting Education 23 (4): 521-33.

Rokhman, Wahibur. 2010. "The Effect of Islamic Work Ethics on Work Outcomes." EJBO-Electronic Journal of Business Ethics and Organization Studies 15 (1). Business and Organization Ethics Network (BON): 21-28.

Saiful, Ahmad, Azlin Puteh, Norlela Kamaluddin, Siti Khadijah, and Abdul Manan. 2011. "Unstoppable Fraud, Scandals and Manipulation - An Urgent Call for an Islamic-Based Code of Ethics." In International Conference on Sociality and Economics Development, 10:474-78.

Sakti, Ali. 2013. "Mapping of Conditions and Potential of BMT : 
Partnership to Expand the Market and Linkage of Islamic Banking Services to the Micro Enterprises." Al-Muzara'ah I (1): 1-18.

Salin, Ahmad Saiful Azlin Puteh; Ab Manan, Siti Khadijah; Nawawi, Anuar. 2017. "The Role of Islamic Ethics to Prevent Corporate Fraud." International Journal of Business and Society 18 (September): 113-28.

Sarosa, Samiaji. 2012. Qualitative Research Principles. Jakarta: Indeks.

Suprapto, Hadi. 2011. "Pembobolan Bank Kian Marak.” Vivanews.Com.

Syed, Jawad, and Abbas J Ali. 2010. "Principles of Employment Relations in Islam: A Normative View." Employee Relations 32 (5). Emerald Group Publishing Limited: 454-69.

Triyuwono, Iwan. 2004. "Amanah), the Divine Symbol: Interpretations in the Context of Islamic Banking and Accounting Practices." In Fourth Asia Pacific Interdisciplinary Research in Accounting Conference, 1-20.

Tuanakotta, Theodorus M.2007. Akuntansi Forensik Dan Audit Investigatif. Jakarta: Lembaga Penerbit Fakultas Ekonomi Universitas Indonesia.

Viva, Tim. 2011. "Pembobolan Marak, Bank Syariah Lebih Aman?" Vivanews.Com.

Wisker, Zazli Lily, and Vikinta Rosinaite. 2016. “The Effect of Religiosity and Personality on Work Ethics : A Case of Muslim Managers." Science Journal Of Business And Management 4 (1999): 1-9. doi:10.11648/j.sjbm.s.2016040101.11.

Yin, Robert K. 2011. Qualitative Research from Start to Finish. New York: The Guilford Press.

Zahrah, Novia, Siti Norasyikin, Binti Abdul, Shamsul Huda Binti, Abdul Rani, Bidayatul Akmal, and Binti Mustafa. 2016. 
"The Relationship between Islamic Religiosity, Islamic Work Ethics and Job Performance." In The European Proceedings of Social \& Behavioural Sciences, 710-16. 